\title{
THE INFLUENCE OF TEMPERATURE ON THE EMBRYONIC DEVELOPMENT OF THE ANNUAL FISH Cynopoecilus melanotaenia (CYPRINODONTIFORMES, RIVULIDAE)
}

\author{
ARENZON, A., LEMOS, C. A. and BOHRER, M. B. C. \\ Centro de Ecologia, Universidade Federal do Rio Grande do Sul, C. P. 15007, \\ CEP 91501-970, Porto Alegre, RS, Brazil \\ Correspondence to: Alexandre Arenzon, Av. Ijuí, 560/202, CEP 90460-200, Porto Alegre, RS, \\ Brazil, e-mail: alex@ecologia.ufrgs.br \\ Received January 18, 2001 - Accepted April 9, 2002 - Distributed November 30, 2002
}

\begin{abstract}
The present study aims to provide data about the time required for Cynopoecilus melanotaenia kept at different temperatures to complete embryonic development. This information can be valuable for optimizing laboratory culture and facilitating future use of this species as a test organism in toxicity tests. Temperature effects on hatching rate are presented as well as information related to embryonic development stages. Eggs were observed daily, from start to finish of embryonic development. Thirteen developmental stages were described. Eggs were kept at two constant temperatures $\left(20^{\circ} \mathrm{C}\right.$ and $\left.25^{\circ} \mathrm{C}\right)$ and at a variable ambient temperature $\left(16-25^{\circ} \mathrm{C}-\right.$ mean $=21^{\circ} \mathrm{C}$, sd $\left.=1.95\right)$, to determine developmental rate (velocity) at each temperature. A shorter incubation period was necessary to complete development at $25^{\circ} \pm 1{ }^{\circ} \mathrm{C}$. However, all embryos kept at this temperature hatched with morphological defects, which prevented their survival. No significant difference in developmental time period $(\mathrm{p}=0.05)$ was observed at the $20^{\circ} \mathrm{C}$ and $16^{\circ}-25^{\circ} \mathrm{C}\left(\right.$ mean $=21^{\circ} \mathrm{C}$, sd $\left.=1.95\right)$ temperatures.
\end{abstract}

Key words: annual fish, temperature, Cynopoecilus melanotaenia, embryonic development.

\section{RESUMO}

\section{A influência da temperatura no desenvolvimento embrionário do peixe anual Cynopoecilus melanotaenia (Cyprinodontiformes, Rivulidae)}

$\mathrm{O}$ presente trabalho visa estabelecer informações referentes ao tempo requerido para embriões de Cynopoecilus melanotaenia, mantidos em diferentes temperaturas, completarem seu desenvolvimento embrionário. Esses dados são importantes na otimização de cultivos dessa espécie em laboratório e podem facilitar seu futuro uso como organismos-teste em testes de toxicidade. O efeito da temperatura na taxa de eclosão e informações sobre os estágios de desenvolvimento embrionário são apresentados. Os ovos foram observados diariamente, do início até o final do desenvolvimento embrionário. Foram descritos 13 estágios de desenvolvimento. Os ovos foram mantidos a duas temperaturas constantes $\left(20^{\circ} \mathrm{C}\right.$ e $\left.25^{\circ} \mathrm{C}\right)$ e a uma temperatura variável $\left(16-25^{\circ} \mathrm{C}-\right.$ média $=21^{\circ} \mathrm{C}$, desvio $\left.=1,95\right)$, a fim de determinar a velocidade de desenvolvimento para cada temperatura. Foi necessário menor período de incubação para completar o desenvolvimento a $25^{\circ} \pm 1^{\circ} \mathrm{C}$. Entretanto, todos os embriões mantidos a essa temperatura eclodiram, apresentando malformações morfológicas que inviabilizavam sua sobrevivência. Não foi observada diferença estatisticamente significativa $(\mathrm{p}=0,05)$ no tempo necessário para completar o desenvolvimento embrionário nos embriões mantidos nas temperaturas de $20^{\circ} \mathrm{C} \mathrm{e}$ $16^{\circ}-25^{\circ} \mathrm{C}$ (média $=21^{\circ} \mathrm{C}$, desvio $=1,95$ ).

Palavras-chave: peixe anual, temperatura, Cynopoecilus melanotaenia, desenvolvimento embrionário. 


\section{INTRODUCTION}

Annual fishes are defined as a group of Cyprinodontiform fish found in seasonally dried out temporary ponds, ditches, and mudholes occurring in some parts of South America and Africa (Myers, 1942). The complete drying out of this aquatic habitat leads to the death of all adults and juveniles. The population survives as buried eggs for up to 18 months (Wourms, 1972a). When the next rainy season comes, a new reproductive cycle begins. Ponds refill and embryos hatch, allowing fast larvae growth. The fishes become sexually mature and spawn repeatedly over a long period (Meyers, 1942, 1952; Peters, 1963; Wourms, 1972a, b, c; Arenzon, 1996; Arenzon et al., 1999; ARENZON et al., 2001).

By undergoing diapause, the embryos can extend their development in order to survive the long dry season (Peters, 1963; Wourms, 1972a, b, c; Markofsky \& Matias, 1977). It has been reported that the diapause of several genera of annual fishes is also regulated by biotic factors, such as substances produced and released into water by adult fishes (Inglima et al., 1981; Levels et al., 1986b), or abiotic factors, such as oxygen concentration (Peters, 1963; Levels et al., 1986a), photoperiod (Levels \& Denucé, 1988), increase in substrate evaporation (Peters 1963; Wourms, 1972c; Matias, 1982), and temperature (Markofsky \& Matias, 1977; Matias \& Markofsky, 1978).

The present study was carried out in order to determine under laboratory conditions the effects of temperature on embryonic development of $C$. melanotaenia. Some information on embryonic development stages is also presented. This type of information is relevant to culture optimization under laboratory conditions and use of this species as a test organism in toxicity tests.

\section{MATERIAL AND METHODS}

Fertilized eggs of C. melanotaenia were obtained from a laboratory population in the Centro de Ecologia at the Federal University of Rio Grande do Sul (Brazil). Fish were kept on a photoperiod of $12 \mathrm{~h}$ light and $12 \mathrm{~h}$ darkness at $20 \pm$ $1^{\circ} \mathrm{C}$. The eggs were deposited in plastic trays filled with peat moss.
Less than 24 hours after spawn, a group of eggs was transferred to petri dishes divided into compartments. Eggs were kept in distilled water adjusted to the conditions presented by Arenzon (1996) (hardness $=20 \mathrm{mg} \mathrm{L}^{-1}$ of $\mathrm{CaCO}_{3}$ and initial $\mathrm{pH}$ of 6.5). The antibiotics Penicillin G (84.3881 $\mathrm{mg} \mathrm{L}^{-1}$ - 1185UI) and Mycostatin (17.7904 $\mathrm{mg} \mathrm{L}^{-1}-$ 562UI) (Wourms, 1972a) were added to the water. Dissolved oxygen concentration and $\mathrm{pH}$ were monitored and adjusted when necessary.

The eggs in the petri dishes were kept in constant darkness, except for brief exposure to light during observation or manipulation. Surface projections of the chorion having been mechanically removed to facilitate observation, developing eggs were observed daily under a dissecting microscope. This information was used as a reference in evaluating the developmental stage of the eggs kept at different temperatures. As a control to the chorion-removed eggs, a group of intact eggs was kept under the same conditions, observed every fortnight, and compared in its development to that of the dechorionated egg group.

Observation of the total developmental time period was performed based on a group of intact eggs kept at three different temperatures: $20 \pm 1^{\circ} \mathrm{C}$, $25 \pm 1^{\circ} \mathrm{C}$, and variable ambient temperature $\left(16^{\circ}\right.$ $25^{\circ} \mathrm{C}$, mean $\left.=21^{\circ} \mathrm{C}, \mathrm{sd}=1.95\right)$. Each group of eggs was kept in closed plastic bags with peat moss, as described by Katz (1993).

Every ten days, the eggs were manually separated from the substrate and observed through a stereoscopic microscope in order to verify the embryonic developmental stage. The observations were repeated four times at each temperature.

After completing development (based on the developmental stages previously observed), the eggs were transferred from the substrate to $40 \mathrm{ml}$ glass beakers with adjusted distilled water as previously described. The eggs kept at the same temperature used in the embryonic development experiment. This was to observe the hatching rate induced by substrate hydration. The hatching process starts a few hours after substrate hydration, as reported by Lacerda (1969).

The results were analyzed statistically using Analysis of Variance (ANOVA), and treatment means were compared with the Tukey complementary test; significance accepted was $\mathrm{p}<0.05$. 


\section{RESULTS AND DISCUSSION}

As can be seen in Table 1, embryos of $C$. melanotaenia spent less time at $25^{\circ} \pm 1^{\circ} \mathrm{C}$ to complete their embryonic development. However, all embryos incubated at this temperature hatched with gross morphological abnormalities, and remained motionless, thus making their survival impossible. At $20^{\circ} \mathrm{C}$ and $16^{\circ}-25^{\circ} \mathrm{C}\left(\right.$ mean $=21^{\circ} \mathrm{C}$, sd $\left.=1.95\right)$, the mean time required to complete embryonic development showed no significant difference $(\mathrm{p}=$ 0.05) (Tables 1 and 2).

The hatching rate, within a period of 24 hours after substrate hydration, did not show any significant difference $(\mathrm{p}=0.05)$ at the three test temperatures (Table 3 ).

To provide criteria for determining developmental rates, the development of $C$. melanotaenia was divided into thirteen stages, based on the first appearance of some easily recognized marked characters.

Stage 1. Perivitelline space is present between the egg envelope and the vitelline membrane. Central lipid droplet is present in the yolk.

Stage 2. Embryonic axis present. The embryo has almost five pairs of somites. Little cephalic organization.

Stage 3. The embryo has ten pairs of somites. Kupffer's vesicle is present.

Stage 4 . The embryo has twenty pairs of somites, with lateral contraction. Optic vesicles are prominent, with some indication of the optic cups. Kupffer's vesicle is no longer present.
Stage 5. Cephalic organization is evident. Heart undergoes contractions. Optic cups are slightly larger than in the previous stage. Eyes are unpigmented.

Stage 6 . The crystalline lenses have appeared in the eyes. Optic cups occupy a greater volume. Either no or few melanophores are present on the trunk. Eyes are still unpigmented or partially pigmented.

Stage 7. Eyes with brown pigment. Melanophores present on the head and trunk.

Stage 8. Eyes with dark-brown or black pigment, with reflex in the central part. Melanophores present on head and trunk have become larger and more numerous.

Stage 9. Pectoral fin bud is present as a lateral condensation of tissue. Some melanophores. Circulating blood cells increase in number.

Stage 10. Pectoral fins are more developed, but no fin rays are present. Eyes are strongly pigmented, and possess a prominent ring of reflecting gold material. Caudal fin touching the embryo heads, but no fin rays present.

Stage 11 . Heavily pigmented eyes contain a blue-colored reflecting material. Eyes undergo spontaneous movements. On the head are large melanophores and several are present near the mouth.

Stage 12. Fins (pectoral and caudal) contain rays. The tip of the caudal fin extends over and beyond the head.

Stage 13. Late stage of development. Embryos exhibit spontaneous jaw movement.

TABLE 1

Time spent to complete embryonic development; hatching rate (at 24 hours after hydration) of eggs of Cynopoecilus melanotaenia kept at $25^{\circ} \pm 1^{\circ} \mathrm{C}, 20^{\circ} \pm 1^{\circ} \mathrm{C}$, and $16^{\circ}-25^{\circ} \mathrm{C}$ (mean $=21^{\circ} \mathrm{C}$, sd $\left.=1.95\right)$.

\begin{tabular}{|c|c|c|c|c|c|c|}
\hline Temp. & \multicolumn{2}{|c|}{$\mathbf{2 5}^{\circ} \mathbf{\pm} \mathbf{1}^{\circ} \mathbf{C}$} & \multicolumn{2}{c|}{$\mathbf{2 0}^{\circ} \mathbf{\pm} \mathbf{1}^{\circ} \mathbf{C}$} & \multicolumn{2}{c|}{$\mathbf{1 6 - 2 5}^{\circ} \mathbf{C}$} \\
\hline Repetition & $\begin{array}{c}\text { Stock period } \\
\text { (weeks) }\end{array}$ & $\begin{array}{c}\text { Hatching in } \\
\mathbf{2 4} \mathbf{~ h}(\mathbf{\%})\end{array}$ & $\begin{array}{c}\text { Stock period } \\
\text { (weeks) }\end{array}$ & $\begin{array}{c}\text { Hatching in } \\
\mathbf{2 4} \mathbf{~ h}(\mathbf{\%})\end{array}$ & $\begin{array}{c}\text { Stock period } \\
\text { (weeks) }\end{array}$ & $\begin{array}{c}\text { Hatching in } \\
\mathbf{2 4} \mathbf{~ h}(\boldsymbol{\%})\end{array}$ \\
\hline 1 & 12.9 & 85.5 & 14.4 & 100.0 & 13.0 & 100.0 \\
\hline 2 & 7.3 & 62.9 & 13.6 & 93.1 & 14.9 & 90.0 \\
\hline 3 & 8.3 & 66.7 & 14.1 & 100.0 & 16.0 & 80.7 \\
\hline 4 & 11.9 & 82.6 & 16.0 & 100.0 & 14.3 & 93.0 \\
\hline Mean & 10.1 & 74.9 & 14.5 & 97.7 & 14.5 & 91.0 \\
\hline SD & 2.7 & 12.0 & 1.0 & 4.0 & 1.2 & 8.1 \\
\hline CV $(\%)$ & 26.8 & 16.0 & 7.2 & 4.1 & 8.6 & 8.9 \\
\hline
\end{tabular}


TABLE 2

Statistical analysis with the Tukey Test comparing the time spent to complete embryonic development of eggs of Cynopoecilus melanotaenia kept at $25^{\circ} \pm 1^{\circ} \mathrm{C}, 20^{\circ} \pm 1^{\circ} \mathrm{C}$, and $16^{\circ}-25^{\circ} \mathrm{C}\left(\right.$ mean $\left.=21^{\circ} \mathrm{C}, \mathrm{sd}^{\prime}=1.95\right)$.

\begin{tabular}{|c|c|c|c|c|c|c|}
\hline \multirow{2}{*}{ Group } & Identification & \multirow{2}{*}{$\begin{array}{c}\text { Transformed } \\
\text { mean }\end{array}$} & \multirow{2}{*}{$\begin{array}{c}\text { Original } \\
\text { mean }\end{array}$} & $\mathbf{1}$ & $\mathbf{2}$ & $\mathbf{3}$ \\
\hline 1 & $25^{\circ} \mathrm{C}$ & 10.100 & 10.100 & 1 & & \\
\hline 2 & $20^{\circ} \mathrm{C}$ & 14.525 & 14.525 & $*$ & $\backslash$ & \\
\hline 3 & $16-25^{\circ} \mathrm{C}$ & 14.525 & 14.525 & $*$ &. & $\backslash$ \\
\hline
\end{tabular}

$*$ = significant difference $(\mathrm{p}=0.05) ; .=$ no significant difference.

Tukey value $(3.9)=3.95 ; \mathrm{s}=3.335$

TABLE 3

Statistical analysis with the Anova comparing hatching rate (at 24 hours after hydration) of eggs of Cynopoecilus melanotaenia kept at $25^{\circ} \pm 1^{\circ} \mathrm{C}, 20^{\circ} \pm 1^{\circ} \mathrm{C}$, and $16^{\circ}-25^{\circ} \mathrm{C}\left(\right.$ mean $=21^{\circ} \mathrm{C}$, sd $\left.=1.95\right)$.

\begin{tabular}{|l|c|c|c|c|}
\hline \multicolumn{1}{|c|}{ Source } & DF & SS & MS & F \\
\hline Between & 2 & 1989.687 & 994.843 & 1.768 \\
\hline Within (Error) & 9 & 5063.643 & 562.627 & \\
\hline Total & 11 & 7053.329 & & \\
\hline
\end{tabular}

Critical $\mathrm{F}$ value $=4.26(0.05,2,9)$

Since $\mathrm{F}<$ Critical F FAIL TO REJECT Ho: All groups equal.

No difference in embryonic development was observed between the dechorionated eggs and the control group. Nevertheless, some embryos did not survive nearly as long after the secondary chorionic envelope had been removed.

According to Carter \& Wourms (1991), annual fish development differs markedly from that of typical non-annual teleost fish due to the occurrence of embryonic diapause and the presence of a phase in which embryo-forming cells disperse and subsequently reaggregate. The early embryonic developmental stages, corresponding to the dispersion and reaggregation cell phases, described by Wourms (1972a, b, c) and Avni \& Soin (1974), have not been described here.

According to Wourms (1972a), three diapause stages are expected to be observed in the embryology of annual fish. In C. melanotaenia the two first stages are facultative and the last is obligatory. The first diapause can occur at the dispersed cell stage, when the amoeboid cells are randomly distributed. The second diapause stage may occur between the forth and fifth stage. Resumption of heart contractions indicates its end. The third diapause occurs during stage thirteen, the pre-hatching stage. This last diapause stage was the most evident after the bradycardia phase was observed.

Regarding the use of juveniles of $C$. melanotaenia as a test organism in toxicity tests, stocks at $20^{\circ} \pm 1^{\circ} \mathrm{C}$ or a variable ambient temperature between $16^{\circ}-25^{\circ} \mathrm{C}\left(\right.$ mean $\left.=21^{\circ} \mathrm{C}, \mathrm{sd}=1.95\right)$ are recommended. At these temperatures, we did not observe any significant difference in the mean time spent to complete embryonic development (Table 3 ). Since the embryos need a longer period to complete their development at these temperatures, they can also be stocked for a longer period. Egg incubation at $25^{\circ} \pm 1^{\circ} \mathrm{C}$ is not recommended since the juveniles quickly perish. 
Acknowledgments - To Laura R.P. Utz and Claudine Gus for their suggestions and review.

\section{REFERENCES}

ARENZON, A., 1996, Biologia e ecologia do annual fish Cynopoecilus melanotaenia (Reagan 1912), visando seu uso como organismo-teste em testes de toxicidade (Cyprinodontiformes, Rivulidae). M. Sc. Thesis, Univ. Federal do Rio Grande do Sul, Porto Alegre, 118p.

ARENZON, A., PERET, A. C. \& BOHRER, M. B. C., 1999, Reproduction of the annual fish Cynopoecilus maelanotaenia (Regan 1912) based on a temporary water body population in Rio Grande do Sul State, Brazil. Hydrobiologia, 411: 65-70.

ARENZON, A., PERET, A. C. \& BOHRER, M. B. C., 2001, Growth of the annual fish Cynopoecilus maelanotaenia (Regan 1912) based on a temporary water body population in Rio Grande do Sul State, Brazil. Rev. Brasil. Biol., 61(1): 117-123.

AVNI, A. A. \& SOIN, S. G., 1974, Adapatative characteristics of the embryogeny of Nothobranchius guentheri in connection with existence in temporary tropical habitat. Journal Ichthyol., 4(5): 735-746.

CARTER, C. A. \& WOURMS, J. P., 1991, Cell behavior during early development in the South American annual fishes of genus Cynolebias. Journal of Morphology, 210: 247-266.

INGLIMA, K., PERLMUTTER, A. \& MARKOFSKY, J., 1981, Reversible stage-specific embryonic inhibition mediated the presence of adults in the annual fish, Nothobranchius neumanni. J. Exp. Zool., 193: 137-146.

KATZ, D., 1993, Mantaining and breeding Cynolebias. J. Am. Killifish Asso., 26(1): 24-31.

LACERDA, T. P., 1969, Estudos sobre peixes anuais da região de São Leopoldo. Dissertation, Univ. do Vale dos Sinos, São Leopoldo, 65p.

LEVELS, P. J., van TITS, B. \& DENUCÉ, J. M., 1986a, The effect of the of adult fishes, gonad homogenates and embryo homogenates on the dispersion-reaggregation phase during early embryonic development of the annual fish, Nothobranchius korthausae. J. Exp. Zool., 240: 259-264.
LEVELS, P. J., GUBBELS, R. E. M. B. \& DENUCÉ, J. M., 1986b, Oxygen consumption during embryonic development of the annual fish Nothobranchius korthausae, with special reference to diapause. Comp. Biochem. Physiol., 84A: 767-770.

LEVELS, P. J. \& DENUCÉ, J. M., 1988, Intrinsic variability in the frequency of embryonic diapause of the annual fish Nothobranchius korthausae, regulated by light: dark cycle and temperature. Env. Biol. of Fishes, 22(3): 211224

MARKOFSKY, J. \& MATIAS, J. R., 1977, The effects of temperature and season of collection on the onset and duration of diapause in embryos of the annual fish Nothobranchius guentheri. J. Exp. Zool., 202: 49-56.

MATIAS, J. R. \& MARKOFSKY, J., 1978, The survival of embryos of the annual fish, Nothobranchius guentheri exposed to temperature extremes and the subsequent effects on embryonic diapause. J. Exp. Zool., 204: 219228

MATIAS, J. R., 1982, Embryonic diapause in annual fishes: evaporative water loss and survival. Experientia, 38: 1315-1317.

MYERS, G. S., 1942, Studies on South American freshwater fishes I. Stanford Icht. Bull., 2: 89-114.

MYERS, G. S., 1952, Annual fishes. Aquarium Journal (San Francisco), 23: 125-141.

PETERS, N., 1963, Embryonale Anpassungen oviparer Zahnkarpfen aus periodisch austrocknenden Gewässern. Int. Rev. Ges. Hydrobyol., 48: 257-313.

WOURMS, J. P., 1972a, The developmental biology of annual fishes. I. Stages in the normal development of Astrofundulus myersi Dahl. J. Exp. Zool., 182: 143-168.

WOURMS, J. P., 1972b, The developmental biology of annual fishes. II. Naturally occurring dispersion and reaggregation of blastomeres during the development of annual fish eggs. J. Exp. Zool., 182: 169-200.

WOURMS, J. P., 1972c, The developmental biology of annual fishes. III. Pre-embryonic and embryonic diapause of variable duration in the eggs of annual fishes. J. Exp. Zool., 182: 389-414. 